detailed analyses of stems of different ages and a consideration of the results obtained of growth in relation to rainfall and temperature lead to some very interesting conclusions. Examination of trunks of pine and redwood shows that the annual rate of growth is not the same at the stump and at different heights in the trunk, and that it is greater toward the centre than towards the periphery. No definite correlation is found between growth and rainfall and growth and temperature, and the conclusion drawn is that the annual growth of the specimens examined is dependent on the general complex of environmental conditions and not on any one particular factor.

A further contribution to this study has recently been published in the Journal of the College of Agriculture, Hokkaido Imperial University, Sapporo, Japan. ${ }^{2}$ The experiments, which took place in the University Botanic Garden at Sapporo, were conducted to show the influence of meteorological factors on the growth of trees, or, more precisely, on the girth of the trunk. Prof. Hirokichi Nakashima was fortunate in being able to select a healthy young specimen of Abies Mayriana, about 50 years old, which was growing a convenient distance from a meteorological station.

Until recent years it was supposed that the girth of the stem increased continually from spring to autumn, and that in winter during the resting period the girth remained unaltered. The experiments, however, showed that even in winter appreciable increase and diminution in girth took place, depending chiefly on meteorological factors. In fact each cycle of development may be divided into four periods. During the vegetation period, from the end of April to the end of October, precipitations proved the most important factor. The relations between transpiration and absorption were the determinants through the autumnal transition period, the month of November, and the late spring period March and April. During the resting period, from mid-December to the beginning of March, the temperature of the air was the chief factor. Prof. Nakashima has been able to express these relations in formulæ. The conclusions drawn are that increase in girth depends either on growth or on the swelling of water-containing tissue ; changes in girth are connected with transpiration and absorption; increased transpiration without corresponding water-absorption by the roots causes decrease in girth; prevention or reduction of transpiration during absorption causes swelling of the stem, and, generally, increase and decrease of girth are closely connected with meteorological conditions.

The article is accompanied by the daily meteorological observations and experimental records of the whole period of five years during which the experiment lasted. The apparatus used for measuring the varying size of the stem was Friedrichs Zuwachs-autograph.

¿ "Öber den' Einfluss meteorologischer Faktoren auf den Baumzuwachs, (I) Über den Einfluss auf den Stammumfang eines Tannenbaumes," by Prof. Hirokichi Nakashima, Journal of the College of Agriculture, Hokkaido the University, Sapporo, November 1924

\section{Haddock Biology.}

THE first part of a paper on the biology of the haddock, by Mr. Harold Thompson, was referred to in NATURE, August 30, I924, p. 333. The second part, on the frequency and distribution of the age classes in 1923 , which has recently been issued, ${ }^{1}$ gives an account of later investigations. In the first part it had been shown that the year I920 had produced

${ }^{1}$ Fishery Board for Scotland: Scientific Investigations, 1924. No. I, Haddock Biology; No. 2, Frequency and Distribution of the Age Classes in I923. By Harold Thompson. Pp. $48+4$ plates. (Edinburgh and I.ondon H.M. Stationery Office, I924.) 5s. net. a remarkably large brood of young haddock, which in 1922 were beginning to show in the commercial catches as two-year-old fish. We now learn that in I923, as Mr. Thompson had ventured to predict, these fish had become the mainstay of the North Sea haddock market, and that they constituted 70.5 per cent. of all the haddock captured, so far as these were sampled.

The years I92I and I922 were both failures so far as the young brood of haddock in the North Sea was concerned, but it is pleasing to note that I 923 was one of the best years on record. If all goes well with the brood, these fish should become prominent in the commercial catches in 1926 as three-year-old fish. Mr. Thompson was able düring 1923, by a detailed study of the scales of this group of haddock, to establish still more closely the relation between the growth of the scale and the growth of the fish. $\mathrm{He}$ shows that the scales first formed on the fish are those which lie immediately below the third dorsal fin, and if scales from this position in older fishes are selected for examination, it will be found that the length of the fish at the end of each growth-year can be determined correctly on the assumption that the growth of the fish is directly proportional to the growth of the scale. On the other hand, scales from below the second dorsal fin will'give a calculated result about half a centimetre short, and those from below the pectoral fin $2.75 \mathrm{~cm}$. short. This is an important point to have established and will clear up many of the difficulties which those working at problems of the growth-rate of fishes have.encountered.

Further observations are recorded on haddock from Iceland, the Faroes, and from the Norwegian coast. The rate of growth of Iceland and Faroe haddock appears to be much greater than that of North Sea fish, but in Iceland the rate decreases from the south coast, by west and north to the east coast, where it is smallest. Good survival years for the brood at Faroe, Iceland, and Norway differ from each other and rom those of the North Sea.

\section{University and Educational Intelligence.}

ABERDEEN.-At the graduation ceremony held on April I, the degree of D.D. was conferred on the Right Rev. E. W. Barnes, F.R.S., Bishop of Birmingham.

LoNDON.-The two following courses of free public lectures at King's College are announced : " Problems of Modern Physics," Prof. W. Wien, on April 21, 22, and 23 ; and "Recent Advances in the Study of Living Cells," Prof. R. Chambers, on April 27, 28, and 29. The lecture hour in each case will be 5.30 .

The Council of the University College of Southampton is to award two open exhibitions in engineering to candidates who may or may not be now resident in the district. The awards will be made on the recommendation of the Engineering Faculty Board without formal examination, provided the candidates have matriculated and are prepared to read for a degree in engineering.

THREE open scholarships, each of the yearly value of $4 \mathrm{ol}$., some bursaries of $20 l$., and others covering the tuition fees in commerce are being offered in competition by University College, Leicester. The examination will be held at the College in June. Particulars may be had from the secretary.

If industrial prospects in Great Britain are at present clouded, good progress can be recorded in

No. 2893 , VOL. I I 5 ] 
the direction of improved social service. The activities of the Carnegie United Kingdom Trust, as set forth in the eleventh annual report, may be summarised as an attempt to restore to the English people the amenities of life which their forefathers enjoyed, and of which they were deprived by an over-rapid development of the factory system. The library policy of the Trust has, as is well known, been directed to the provision of facilities for reading in the rural districts by the establishment of County Library schemes reinforced by Central Loan Collections. Grants for the establishment of County Libraries have now been made in eighty-six counties in the United Kingdom of Great Britain and Ireland, and in the course of a few years these will all be on an independent basis. The development, however, of the Central Loan Collections on self-supporting lines presents many difficulties. The cost of the administration of these national book stores is likely to increase more rapidly than the income from the contributory libraries, and it is clear that in the long run some assistance will have to be provided by the State. In the meantime the grant to the London Central Library has been increased from roool. to 3000 ., at which sum it will be maintained for the next four years. Other activities of the Trust in the direction of fostering the national talent in musical composition, the drama, and folk-dancing continue to show satisfactory results. The Margaret Carnegie Hostel for girls at Portree was officially opened last October, and a large grant has been made for the purchase of a building in East London to be used as a hostel for boys.

Visual Education Departments in Educational Institutions form the subject of a report published in Bulletin, I924, No. 8 of the United States Bureau of Education. Of $7^{8}$ State universities and State colleges, 20 have departments sufficiently well organised to employ special officials to handle visual aids. They are generally organised as parts of the university extension divisions of these institutions, but the work is not entirely extra-mural, and the departmental heads attend faculty meetings. The growth of these departments is described as a teacher movement and not a commercial development: on the contrary, it is a development in despite of the commercial exchanges, which have sided with the theatres in their opposition to supplying films to educational institutions. Five departments undertake the actual production of films. Columbia University has a course in moving-picture production, and the University of Nebraska is said to have built a 20,000-dollar moving-picture studio on its campus. The University of Wisconsin has purchased the negatives of a large group of educational films, and sells the prints direct to other institutions at about 6 o dollars per reel of rooo feetconsiderably less than what commercial firms charge. The United States Department of Agriculture and the Bureau of Mines have done much to popularise instruction in agriculture and in mining and metallurgy by the use of films and slides. The Bureau of Mines contrives to produce films without any expense to the Government beyond the salary of an engineer, who assists in planning and directing the work to assure its being worthy of circulation, the whole of the rest of the cost of production and making the copies being borne by the industries filmed. Colleges, high-schools, and churches are the largest users of these films. Though films figure largely in the report, they are by no means universally considered the most useful of visual aids. The slide has a decisive majority vote for usefulness. Much use is also made of stereographs and exhibits of objects from museums.

\section{Early Science at Oxford.}

April I3, I686. A discourse concerning Hydraulic Engines, drawn up by Mr. King of Dublin, was communicated by Mr. Ash: the Society ordered their thankes for this ingenious discourse, both to Mr. Ash, and Mr. King.

Mr. Caswel communicated a Mathematicall paper containing the Solutions of severall problemes, composed by Mr. Baker of Bishops Nymton in Devonshire.

April r4, I685. Mr. President communicated a farther discourse concerning ye Air's Gravity observed in ye Baroscope, occasioned by that of Dr. Garden read ye last meeting. $\mathrm{He}$ also comunicated ye following observation; that at Dover, on March I9 last past, (which was two daies after the last quarter of ye Moon) there was observed this extraordinary in ye Tide: After it had flowed some time, it ebbed two foot; then flowed again, and then ebbed; and after flowed a third time, and so a fourth time : so that there were four flowings, and three ebbings in one Tide.

A Letter from Mr. Cony, dated Rochester March 27 , was read concerning the raining of Fish, as it was supposed to have been in that countrie some time since.-Mr. Cole of Bristoll mentioned a substance proceeding from Calamy oar, which far exceeds, in colour and finenesse, all metalls, beside gold, and silver.

April I5, I684. Mr. Pulleyn informed ye Society, that an Elm, split at Cumnor, during ye late frost, was observed to have Ice in it: It was affirmed that vines have been split this winter, more frequently towards ye South, than any other, point of ye compass; and that they split more in ye Thaw following ye great Frost, than in ye frost itself: ye reason of ye former may be, because vines lye most open to ye South, and partly also (as Mr. Walker imagins) because ye sap-vessells are largest, and ye quantity of ye sap greatest in ye south side of ye vine, as in other Trees. Dr. Smith did himself observe, that ye Cedars of ye Physick garden, raisd from seeds brought out of Syria, bore ye shock of ye frost, without being any way damaged. $\mathrm{Mr}$. Crouch was desired to enquire, whether ye Cedars of Balliol College were any way injured. A Letter dated Aprill roth, from Mr. Aston, Secretary to ye Royall Society, was read; which questioning whether a body, in shape like ye heel of a Shooe, presented by my Lord Bishop of Lincoln, to Dr. Plot, being esteemed as a Petrification of leather, be any thing more then a bare Incrustation. For ye satisfaction both of ourselves, and ye Royal Society, it was ordered, that this (supposed) Petrification should be examined, as to its make, and texture; more especially by boring it: Mr. Wm. Piggot tooke this charge on him.

Three papers of Dr. Lister's concerning thunder \&c. proceeding from Pyrites; and a letter from Sir $R$. Southwell concerning ye compasses of a Ship being changed by lightning, were read.

A Peice of black Brittish Marble, spotted white, found in ye grounds of Mr. Wogan of Bolston in Pembrokeshire (who uses this sort of stone for ye makeing lime) was comunicated to ye Society, by Dr. John Floyd, Vice-chancellor of ye University. It was ordered to be put in the Ashmolean Museum. This led us to discourse of sawing marble. It was affirmed by $\mathrm{Mr}$. Wheeler that Little Veins, called pins by ye stone-cutters, run up and down, and are sometimes so many and so hard, that they dull ye teeth of ye tooles, so that many times it is not worth ye while to worke ye stone. 